\title{
TAKHRIJ AL-HADITS TENTANG PERALATAN MAKAN NABI SAW.
}

\author{
Hairul Hudaya \\ Fakultas Tarbiyah dan Keguruan IAIN Antasari Banjarmasin \\ Email: hud_hud05@yahoo.com
}

\begin{abstract}
For the Muslims, the position of the Prophet Muhammad is not only transmitting the revelations, but also explaining and realizing them in all aspects of his life. Therefore, the description of how and what he ate is included as parts of the hadith. Nevertheless, the practice of hadith can not be separated from the assessment of the quality of these hadith. The results showed that the hadith associated with the Prophet's tableware and Food is authentic both from its sanad and matan. The Hadith can be understood as a form of the humble life style of the prophet. This attitude fits with what is said in the Qur'an and the Hadiths
\end{abstract}

Keywords: Takhrij al-badits, Sanad, Matan

\section{Pendahuluan}

Di mata para sahabat, Nabi Saw. merupakan prototype ideal yang mesti dilihat, diikuti dan diteladani segala perilakunya. Nabi Saw. adalah representasi dari nilai-nilai al-Qur'an itu sendiri sehingga apa yang menjadi kebiasaan Nabi Saw. merupakan gambaran dari nilai al-Qur'an. Hal inilah yang dipahami Aisyah ketika ditanya bagaimana akhlak Nabi Saw. dengan mengatakan bahwa akhlak beliau adalah alQur'an. ${ }^{1}$ Sedang akhlak itu sendiri berarti kebiasaan yang telah menjadi perilaku seseorang tanpa diawali dengan proses berfikir sebelum melakukannya. Atas dasar itu pula, para sahabat mencatat segala hal berkenaan dengan Nabi Saw. hingga hal-hal yang sangat private dalam kaca mata masyarakat modern.

Menurut ulama hadis, sifat, tingkah laku dan prilaku Nabi Saw. sehari-hari merupakan bagian dari kategori sunnah. ${ }^{2}$ Dengan pandangan ini maka seluruh gerakgerik Nabi Saw. tanpa memandang kaitannya dengan aspek hukum dapat dipandang sebagai sunnah yang harus diikuti. Seluruh aspek kehidupan Nabi Saw. mulai dari bagaimana Nabi Saw. beranjak tidur hingga tidur lagi merupakan ajaran dari nilai-nilai Islam yang tercatat dalam kitab-kitab hadis. Termasuk dalam hal ini adalah peralatan yang Nabi Saw. gunakan ketika makan dan apa yang beliau makan.

1 Ahmad ibn Hanbal, Musnad al-Imam Ahmad ibn Hanbal, ditahqiq dan ditakhrij oleh Syu'aib alArnuth dll., juz 41 (Beirut: Mu’assasah al-Risalah, 2001/1421), h. 148.

2 Muhammad 'Ajaj al-Khatib, Ushul al-Hadis: Ulumubu wa Mushthalabubu, (Beirut: Dar al-Fikr, 1989), h. 19 
Terdapat banyak hadis yang berbicara tentang kebiasaan dan tata cara hidup Nabi Saw. termasuk peralatan yang digunakan dan apa yang beliau makan. Untuk mengetahui bagaimana kualitas dan ragam hadis tentang tata cara makan Nabi Saw. maka penulis perlu mengumpulkan seluruh jalur sanad yang terdapat dalam kitabkitab hadis terutama kebiasaan Nabi Saw. tidak makan di atas piring dan meja serta kebiasaan beliau tidak memakan roti yang lembut.

Dalam makalah ini penulis berusaha meneliti kualitas sanad dan matan hadis Nabi Saw. berkenaan dengan peralatan makan yang Nabi Saw. gunakan yakni beliau tidak makan di atas piring dan meja serta tidak makan roti yang lembut.

\section{Takhrij Hadis}

Secara leksikal takhrij berarti keluar, nampak dan jelas. Dalam hal ini, makna takhrij yang populer digunakan ulama ialah al-istinbath (hal mengeluarkan), al-tadrib (hal melatih), dan al-taujih (hal menghadapkan atau menjelaskan). ${ }^{3}$

Adapun takbrij menurut terminologi ulama hadis adalah: 1. Menyebutkan hadis beserta sanadnya, mendiskusikan keadaan sanad dan matannya seperti yang terdapat dalam kitab Sunan al-Tirmizi dan Sunan Abu Dawud. 2. Menyebutkan jalur sanad lainnya untuk memperkuat sanad hadis yang terdapat dalam suatu kitab. 3. Mengembalikan hadis kepada kitab-kitab asalnya dengan menjelaskan kualitasnya. ${ }^{4}$

Yang penulis maksud dengan takhrij al-hadits di sini adalah mengeluarkan hadis dari sumber aslinya dengan mencantumkan sanad dan matannya kemudian menjelaskan kualitas hadis tersebut.

Syuhudi Ismail menyebutkan sedikitnya tiga hal yang menyebabkan pentingnya kegiatan takhrij dalam penelitian hadis yaitu:

1. Untuk mengetahui asal-usul hadis yang akan diteliti

2. Untuk mengetahui seluruh riwayat bagi hadis yang akan diteliti

3. Untuk mengetahui ada atau tidak adanya syahid dan mutabi' pada sanad yang diteliti. ${ }^{5}$

Ada 5 (lima) metode yang ditawarkan ulama hadis dalam proses pelaksanaan takbrij yakni berdasarkan kitab-kitab kumpulan hadis, lafal-lafal hadis, rawi pertama, tematik dan ciri-ciri tertentu. ${ }^{6}$ Dalam pelaksanaan takhrij kali ini penulis menggunakan metode takhrij melalui lafal-lafal hadis (takbrij bi al-fazh) dengan menggunakan kitab Mu'jam Mufahras li Alfaŗb al-Hadits al-Nabawi, CD Program Mausu'ah Hadis Syarif Kutub Tis'ah dan sebagian data diambil dari CD Maktabah Syamilah.

3 Arief Halim, Metodologi Tahqiq Hadis Secara Mudah dan Munasabah, (Malaysia: Univ. Sains Malaysia, 2007), 41.

4 Abu Muhammad Abd al-Hadi, Thuruq Takhrij Hadis Rasul Allah Shalla Allah 'Alaibi wa Sallam, (ttp: Dar al-'Itisham, tth), h. 10.

5 M. Syuhudi Ismail, Metodologi Penelitian Hadis Nabi Saw., (Jakarta: Bulan Bintang, 1992), Cet. I, h. 44.

${ }^{6}$ Ibid, h. 24. M. Syuhudi Ismail kemudian meringkaskan metode takhrij tersebut melalui dua cara yakni takbrij bi alfarh dan takhrij bi al-maudhu'. Llihat, M. Syuhudi Ismail, Metodologi Penelitian Hadis Nabi Saw., (Jakarta: Bulan Bintang, 1988), h. 46. 
Adapun potongan hadis yang menjadi objek kajian dalam penelitian ini adalah:

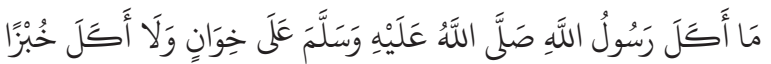

Berdasarkan potongan hadis di atas maka penulis menelusuri dalam kitab $M u^{\prime} j a m$ Mufahras li Alfazh al-Hadis al-Nabawi, CD Program Mausu'ah Hadis Syarif Kutub Tis'ah dan sebagian data dari CD Maktabah Syamilah dengan menggunakan dua lafal kata kunci yakni kata 'خان' dan 'خبز' Kata 'خوان' digunakan karena menurut penulis merupakan kata yang sangat asing didengar dan jarang dimuat dalam hadis Nabi Saw. sehingga memudahkan pelacakan hadis dari sumber asalnya. Sedang kata 'خبز' dimuat dalam banyak kitab hadis. Kata tersebut digunakan sebagai pelengkap pelacakan dari kata خوان sehingga dapat mengcover apa yang tidak dimuat dalam kata pertama. Dari asal kata 'خحان' ditemukan kata 'خوان'. Sedang kata 'خبز' ditemukan dalam kata 'خبز'. Berdasarkan dua kata tersebut ditemukan kelengkapan potongan hadis di atas pada beberapa kitab hadis, yakni:

\begin{tabular}{|c|c|c|c|c|c|}
\hline $\mathrm{NO}$ & Mu'jam Mufahras & $\mathrm{NO}$ & CD Program Mausu'ah & $\mathrm{NO}$ & CD Maktabah Syamilah \\
\hline 3. & $\begin{array}{l}\text { Bukhari, kitab } \\
\text { Ath'imah bab } \\
8 \text { dan bab 24, } \\
\text { Riqaq bab. 16. } \\
\text { Tirmizi, kitab } \\
\text { Ath'imah bab. 1, } \\
\text { Zuhd bab. } 38 . \\
\text { Ibn Majah, bab } \\
\text { Ath'imah no. } 20 . \\
\text { Ahmad bin } \\
\text { Hanbal, juz. III, } \\
\text { h. } 130 .^{7}\end{array}$ & 3. & $\begin{array}{l}\text { Bukhari, kitab al- } \\
\text { Ath'imah, bab al-kbubr, } \\
\text { al-muraqqaq wa al-akl 'ala } \\
\text { al-kbiwan wa sufrah, no. } \\
\text { 4967. Kitab al-Ath'imah } \\
\text { bab ma kana al-Nabi } \\
\text { Saw. wa Ashabubu ya'ku- } \\
\text { luna, no. 4995. Kitab al- } \\
\text { Riqaq, bab Fadhlal-Faqr, } \\
\text { no. 5969. } \\
\text { Tirmizi, kitab al-Zubd } \\
\text { 'an Rasulillah bab ma ja'a } \\
\text { fi Ma'isyah al-Nabi Saw. } \\
\text { wa Ablubu, no. } 2286 . \\
\text { Ibn Majah, kitab al- } \\
\text { Ath'imah bab al-Akl } \\
\text { 'ala al-Khiwan wa } \\
\text { al-Sufrah, no. } 3403 \text { dan } \\
\text { 3404. } \\
\text { Ahmad bin Hanbal, } \\
\text { kitab Baqi Musnad } \\
\text { al-Muktsirin, bab Mus- } \\
\text { nad Anas bin malik, no. } \\
\text { 11876. }\end{array}$ & 3. & $\begin{array}{l}\text { Sunan al-Kubra li } \\
\text { an-Nasai Juz } 4 \text { h. 147, } \\
\text { no. 6625, Sunan al- } \\
\text { Kubra li al-Nasai, Juz } 4 \\
\text { h. 150, no. 6634. } \\
\text { Musnad Abi Ya'la, bab } \\
\text { Qatadah 'an Anas, juz 5, } \\
\text { h. 367, h. 3014. } \\
\text { Musnad al-Bazzar, } \\
\text { bab Musnad Abi } \\
\text { Hamzah Anas bin Ma- } \\
\text { lik, juz II, h. 336, no. } \\
7120,7121 .\end{array}$ \\
\hline
\end{tabular}

7 Dari kata 'kbiwan', potongan hadis di atas terdapat pada empat kitab yakni Bukhari, Tirmizi, Ibn Majah dan Ahmad bin Hanbal. Sedang dari kata 'khubz', hanya ditemukan pada dua kitab yakni Bukhari dan Tirmizi. Lihat, A.J. Wensinck, al-Mu'jam al-Mufahras li Alfadz al-Hadis al-Nabawi, (Leiden: E.J. Bril, 1943), juz. III, h. 6 dan 92.

8 Lihat, CD Program Mausu'ah Hadis Syarif Kutub Tis'ah. 
Berdasarkan informasi dari tiga sumber di atas, ditemukan kelengkapan matan hadis yang tengah diteliti. Berikut adalah bunyi teks hadis secara lengkap:

1. Shahih al-Bukhari, kitab al-Ath'imah, bab al-khubz al-muraqqaq wa al-akl 'ala al-kbiwan wa sufrah, no. 4967.

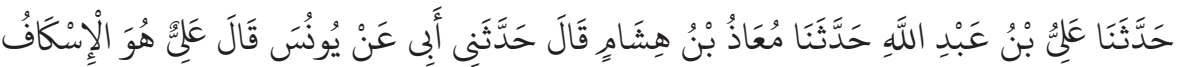

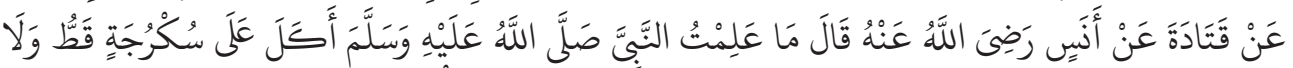

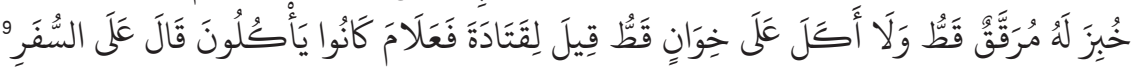

2. Shahih al-Bukhari, kitab al-Ath'imah, bab ma kana al-Nabi Saw. wa Ashabubuya'kuluna, no. 4995.

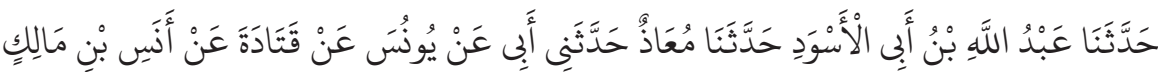

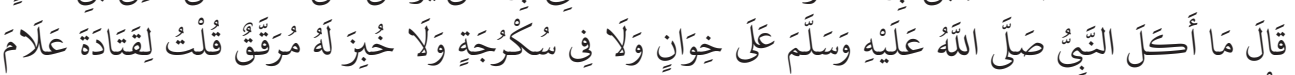

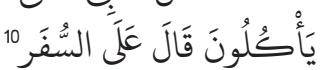

3. Shahih al-Bukhari, kitab al-Riqaq, bab Fadbl al-Faqr, no. 5969 .

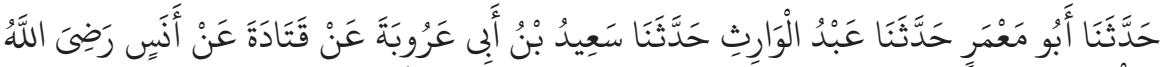

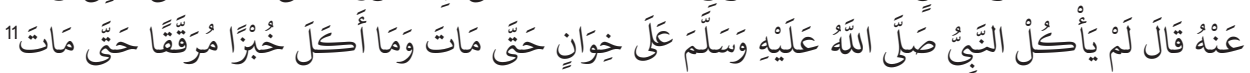

4. Sunan al-Tirmizi, kitab al-Zubd 'an Rasulillah bab ma ja'a fi Ma'isyah al-Nabi Saw. wa Ablubu, no. 2286.

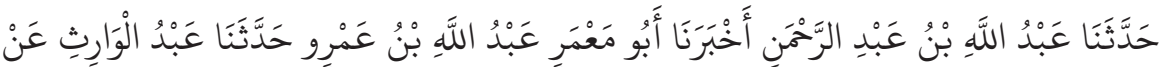

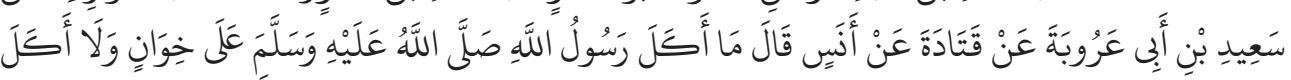

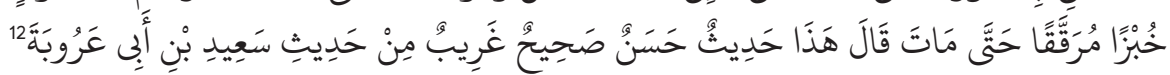

5. Sunan al-Tirmizi, kitab al-Ath'imah 'an Rasulillah bab ma ja'a 'alama kana ya'kulu Rasulullah saw., no. 1788.

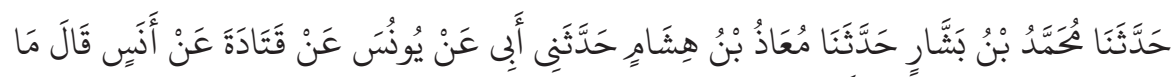

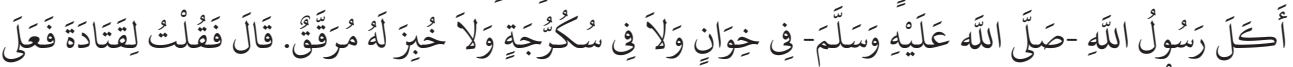

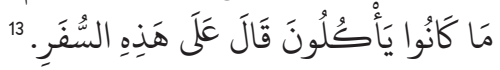

\footnotetext{
9 Abu 'Abd Allah Muhammad bin Isma'il bin Ibrahim bin al-Mughirah bin Bardazabah, Shabih al-Bukhari, (Beirut: Dar al-Kutub al-'Tlmiah, 1992), juz. VI, h. 542

${ }^{10} \mathrm{Ibid}$, h. 550

${ }^{11}$ Ibid, juz. VII, h. 229

${ }^{12}$ Abu 'Isa Muhammad bin 'Isa bin Saurah al-Tirmidzi, al-Jami' al-Shabih wa huwa Sunan al-Tirmidzi, (Beirut: Dar al-Kutub al-'Tlmiyyah, 2000), Juz. III, h. 312

${ }^{13}$ Ibid, Juz. IV, h. 220
} 
6. Sunan Ibn Majah, kitab al-Ath'imah bab al-Akl'ala al-Khiwan wa al-Sufrah, no. 3283.

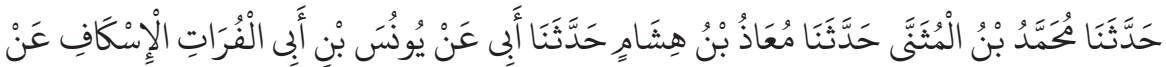

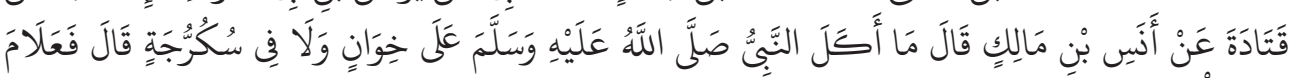

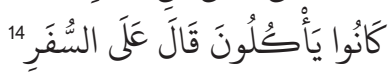

7. Sunan Ibn Majah, kitab al-Ath'imah bab al-Akl'ala al-Khiwan wa al-Sufrah, no. 3284.

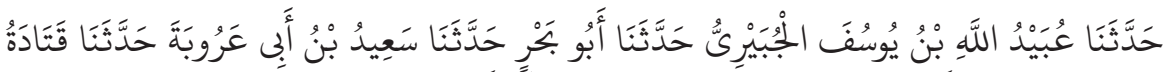

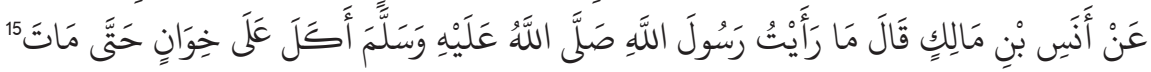

8. Musnad Ahmad bin Hanbal, kitab Baqi Musnad al-Muktsirin, bab Musnad Anas bin malik, no. 11876.

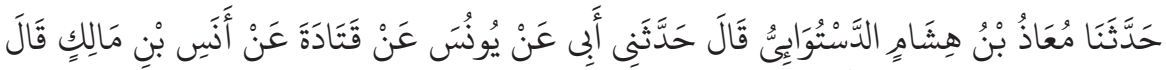

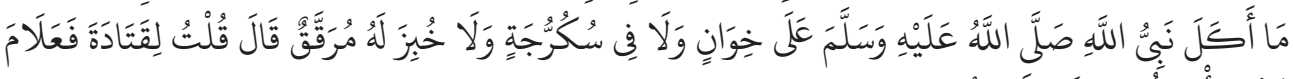

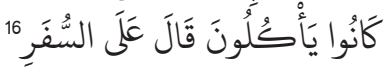

9. Sunan al-Kubra li al-Nasai, Juz 4 h. 147, no. 6625.

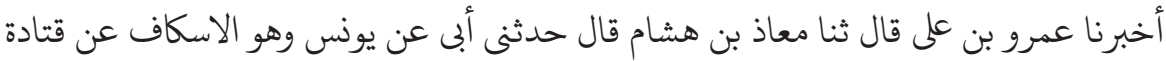

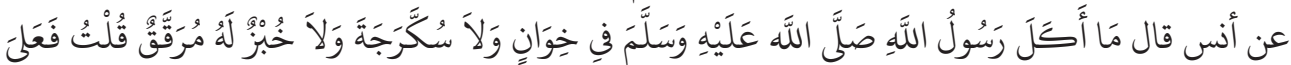

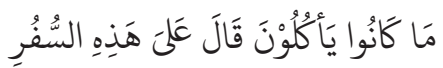

10.Sunan al-Kubra li al-Nasai, Juz 4 h. 150, no. 6634

أخبرنا إسحاق بن إبراهيم قال أنا معاذ بن هشام قال حدثنى أبى عن يونس عن قتادة عن أنس

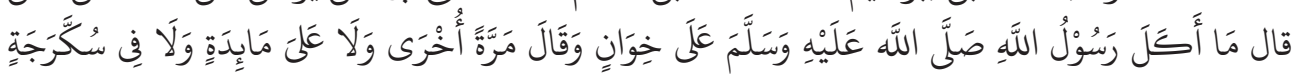

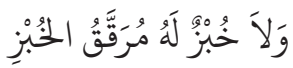

11. Musnad Abi Ya'la, bab Qatadah 'an Anas, juz 5, h. 367, h. 3014.

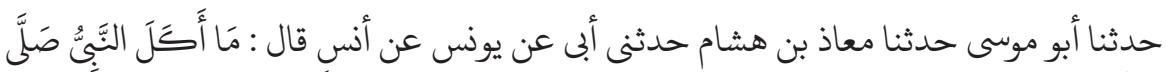

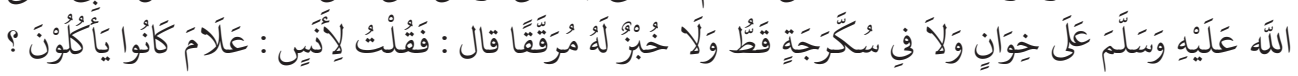

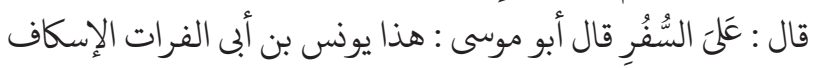
قال حسين سليم أسد : إسناده صحيح : فوسئ : هذال

\footnotetext{
${ }^{14}$ Abu Abd Allah Muhammad bin Yazid al-Qazwini, Sunan Ibn Majah, (Beirut: Dar al-Fikr, 1995), Juz. II, h. 289

${ }^{15}$ Ibid

${ }^{16}$ Abu Abd Allah Ahmad bin Hanbal, Musnad Abmad bin Hanbal, (Riyadh: Bait al-Fakr, 1998), h. 870
} 
12. Musnad al-Bazzar, bab Musnad Abi Hamzah Anas bin Malik, juz II, h. 336

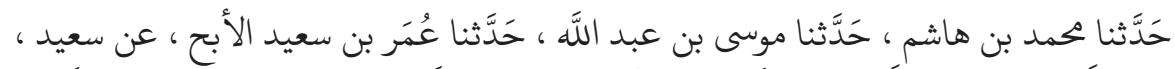

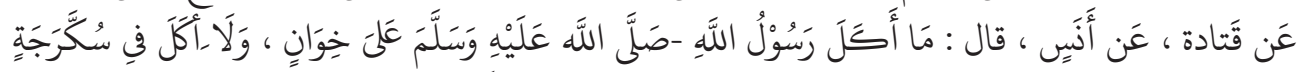

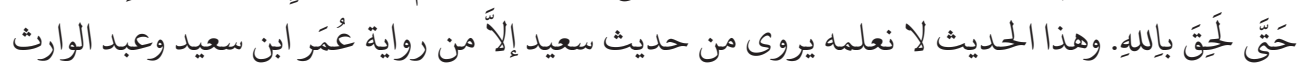

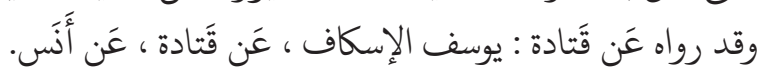

13. Musnad al-Bazzar, bab Musnad Abi Hamzah Anas bin Malik, juz II, h. 336

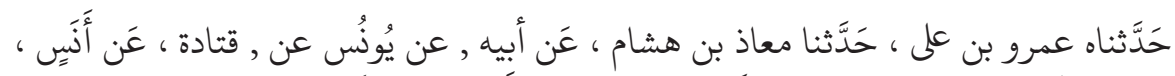

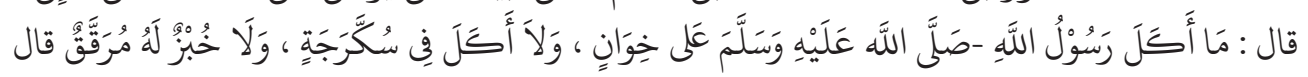

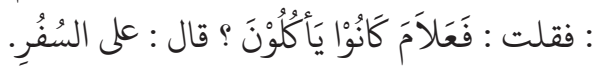

\section{I'tibar Al-Hadits}

Setelah dilakukan takhrij hadis dengan menggunakan tiga sumber pelacakan hadis maka langkah berikutnya adalah melakukan ittibar yakni meneliti semua jalur hadis yang memiliki teks yang sama (bi al-laf:i) maupun maknanya serupa ( $b i$ al-ma'na) untuk melihat ada tidaknya pendukung (corraboration) berupa periwayat yang berstatus syabid (pendukung pada tingkat sahabat) atau mutabi' (pendukung bukan dari sahabat) atau hadis tersebut menyendiri (fard)..$^{17}$

Dengan ditemukannya jalur periwayat lain baik yang berstatus sebagai syabid maupun mutabi akan semakin menguatkan kedudukan hadis tersebut. Apabila jalur periwayat yang semula berstatus dhaif, misalnya, maka derajatnya dapat naik menjadi hasan li ghairibi atau apabila jalur sanadnya yang semula berstatus hasan, dengan adanya syabid atau mutabi' maka hadis tersebut dapat naik statusnya menjadi hadis shahih li ghairibi. ${ }^{18}$ Karenanya, i'tibar mesti dilakukan untuk mengetahui tingkat akurasi periwayatan hadis.

Dalam hal ini, untuk lebih merepresentasikan hadis Nabi Saw. berkenaan dengan tata cara dan kebiasaan makan beliau maka semua jalur sanad hadis dijadikan bahan itibar. Berikut adalah skema i'tibar yang dimaksud.

\footnotetext{
${ }^{17}$ Muhammad 'Ajaj al-Khatib, Ushul al-Hadis ..., h. 367.

${ }^{18}$ Ibid, h. 170.
} 


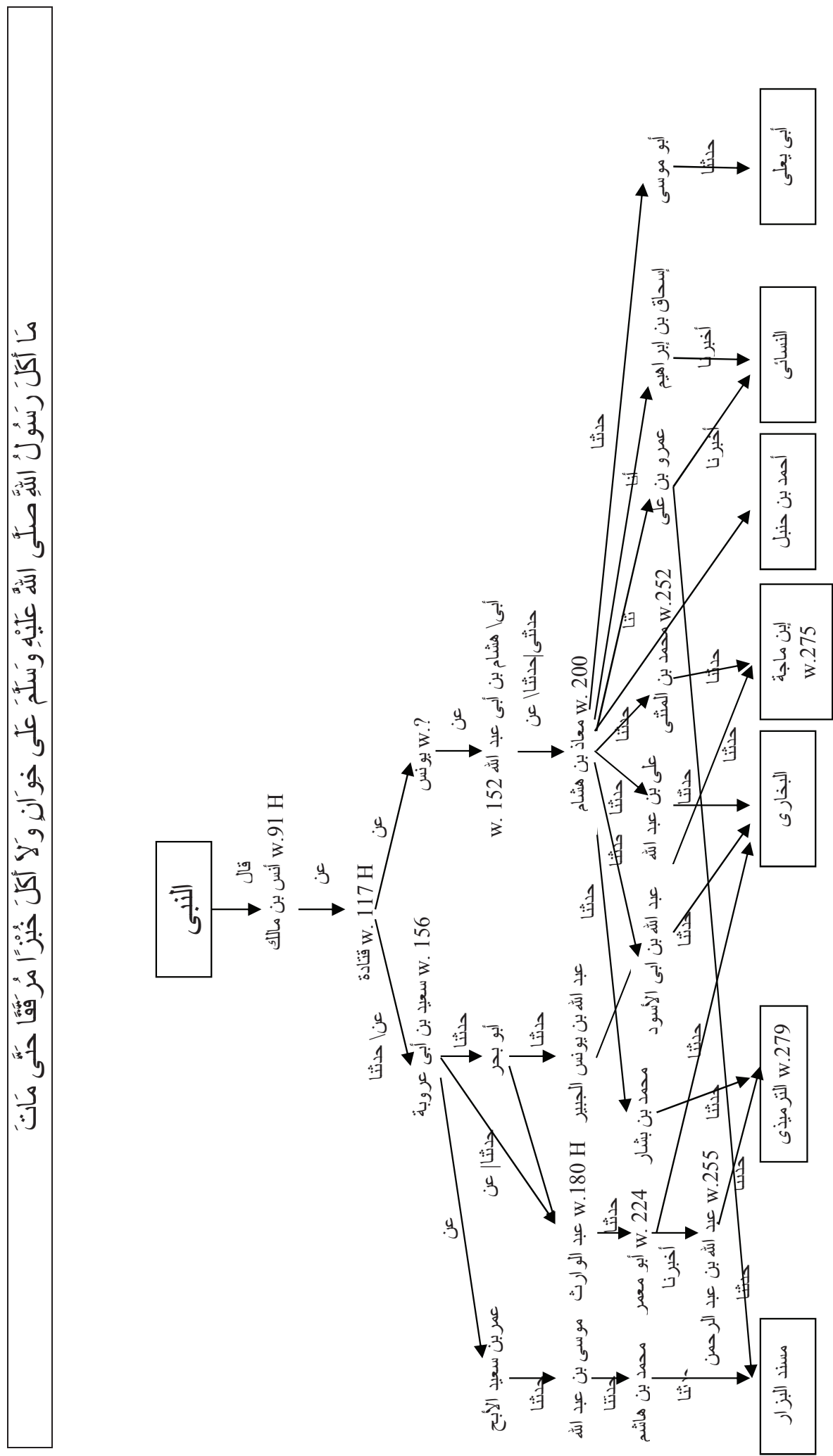


Berdasarkan skema jalur sanad hadis di atas dapat disimpulkan:

1. Setelah memperhatikan seluruh rangkaian sanad hadis pada i'tibar di atas, diketahui bahwa tidak ditemukan jalur periwayatan yang berkedudukan sebagai syabid sebab pada perawi sahabat hanya ditemukan seorang perawi pada semua jalur sanad yakni Anas bin Malik.

2. Terdapat mutabi' ditingkat tabi'in kecil yakni Yunus dan Said bin Abi 'Arubah.

عن, Adapun lambang yang digunakan dalam seluruh jalur periwayatan adalah حدثنا, حدثنى, أخبرنا, أخبرنى.

\section{Kritik Sanad Dan Matan Hadis}

Dalam penelitian ini, jalur hadis yang akan diteliti adalah jalur riwayat al-Tirmizi dari Abd Allah bin Abd al-Rahman.

Jalur periwayatan al-Tirmizi tersebut berbunyi:

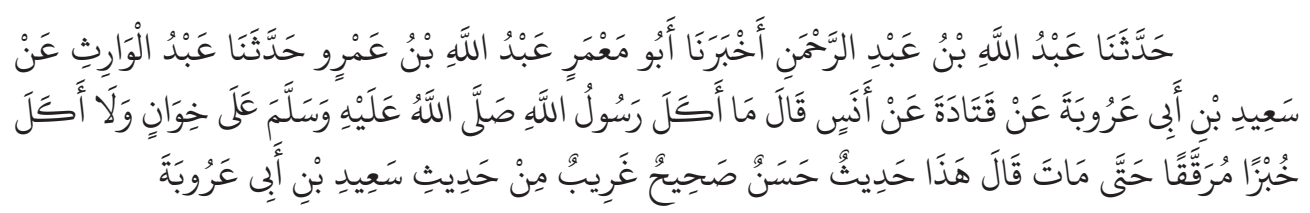

Diriwayatkan dari Abd Allah bin Abd al-Rahman, mengabarkan kepada kami Abu Ma'mar Abd Allah bin 'Amr dan meriwayatkan kepada kami 'Abd al-Warits dari Sa'id bin Abi 'Arubah dari Qatadah dari Anas, ia berkata: Nabi Saw. tidak pernah maka di atas meja makan dan tidak pula memakan roti yang lembut bingga wafat. Tirmizi berkata: 'hadis ini berkualitas hasan sahih gharib dari jalur periwayatan Sa'id bin Abi 'Arubah.'

\section{Kritik Sanad}

Dalam kaedah kesahihan hadis dinyatakan bahwa syarat hadis yang dinilai shahih apabila memenuhi lima kriteria ${ }^{19}$ yakni:

1. Apabila sanad hadis tersebut bersambung mulai dari mukharrijnya sampai kepada Nabi Saw..

2. Seluruh perawi pada jalur sanad tersebut bersifat adil

3. Seluruh perawi bersifat dhabit

4. Tidak terdapat syadz

5. Tidak terdapat 'illah

Dengan lima kriteria di atas dapat dinilai tingkat kualitas suatu hadis. Apabila suatu hadis memenuhi semua kriteria tersebut maka ia dinilai shahih namun bila salah satu kriteria tidak terpenuhi maka akan dinilai dhaif. Tiga kriteria pertama berkenaan dengan kritik sanad sedang dua kriteria terakhir berkaitan dengan sanad dan matan. Untuk mengetahui kualitas persambungan sanad dan ke'adilan serta kedhabitan para

${ }^{19}$ Menurut Shubhi Shalih, hadist shahih adalah hadis musnad yang bersambung sanadnya dengan perawi yang adil lagi dhabit dari perawi yang adil lagi dhabit pula. Semua perawi tersebut sampai kepada Nabi Saw. atau sahabat atau tabi'in dan tidak terdapat syadz serta illah. Lihat, Shubhi Shalih, 'Ulum al-Hadis wa Mushthalabuh, (Beirut: Dar al-'Ulum li al-Malayin, 1988), h. 145. 
perawinya dilakukan penelitian tentang biografi perawi. Adapun perawi dari jalur riwayat al-Tirmizi adalah sebagai berikut: 1. Anas bin Malik (perawi I); 2. Qatadah (perawi II); 3. Sa'id bin Abi 'Arubah (perawi III); 4. 'Abd al-Warits (perawi IV); 5. Abu Ma'mar (perawi V); 6. Abd Allah bin Abd al-Rahman (perawi VI); 7. Al-Tirmizi (mukharrij). Berikut akan dipaparkan mengenai biografi perawi hadis yang menjadi fokus penelitian.

a. Biografi para Perawi Hadis

Dalam menilai kualitas ketersambungan sanad hadis mulai dari perawi awal sampai pada mukharrij hadis, ulama mengandalkan kitab-kitab biografi perawi hadis. Ketersambungan sanad dapat ditentukan melalui tahun lahir dan wafat seorang perawi, tempat tinggalnya, perjalanannya dalam menuntut ilmu dan yang penting juga adalah hubungan guru dan murid antar perawi hadis. Sedang keadilan dan kedhabitan perawi didapat dari informasi penulis kitab biografi perawi tentang sifat, sikap dan kemampuan daya ingatnya selama meriwayatkan hadis.

Untuk kesempurnaan biodata para perawi hadis, penulis berusaha menggabungkan data biografi perawi dari kitab-kitab rijal hadis dengan informasi yang diambil dari CD Program Mausu'ah al-Hadis al-Syarif.

Berikut adalah biografi semua perawi hadis yang tengah diteliti:

1. Jalur Riwayat al-Tirmizi

\section{a. Imam al-Tirmizi}

Nama lengkapnya adalah Muhammad bin 'Isa bin Saurah bin Musa bin alDhahhak, ibn al-Sakan al-Sulamiy Abu 'Isa al-Tirmizi. Ia wafat pada bulan Rajab tahun $279 \mathrm{H}$.

Ia mempunyai banyak guru di Khurasan, Irak dan Hijaz.

Diantara murid-muridnya adalah Abu Hamid Ahmad bin 'Abd Allah bin Dawuf al-Maruzi, al-Haitsam bin Kalib, Muhammad bin Mahbub, dll.

Penilaian kritikus hadis terhadap dirinya. Ibn Hibban memasukkannya dalam kitab 'Tsiqah'nya. Al-Khalili berkata: disepakati tsiqah. Al-Idrisi berkata: ia merupakan salah seorang tokoh yang diikuti dalam bidang ilmu hadis dan telah mengarang kitab 'jami', 'tawarikh', 'illal. ${ }^{20}$

\section{b. 'Abd Allah bin 'Abd al-Rahman}

Nama lengkapnya 'Abd Allah bin 'Abd al-Rahman bin al-Fadhl bin Bahram bin 'Abd al-Shamad al-Tamimi al-Darimi, Abu Muhammad al-Samarqandi. Ia wafat ketika berumur 74 tahun di tahun $255 \mathrm{H}$ pada hari Tarwiyah dan dimakamkan di hari 'Arafah pada hari Jum'at.

Diantara guru-gurunya adalah al-Nadhr bin Syumail, Abi al-Nadhr Hasyim bin al-Qasim, Marwan bin Muhammad al-Thathariy, Yahya bin Hassan, Ya'la bin 'Ubaid, Abi 'Ashim, Abi Nu'aim dll.

Diantara murid-muridnya adalah al-Tirmizi, Muslim, Abu Dawud, Bukhari, Bundar, Abu Zur'ah, Abu Hatim, 'Abd Allah bin Ahmad bin Hanbal, 'Isa bin Umar

${ }^{20}$ Ahmad bin 'Ali bin Hajar Syihab al-Din al-'Asqalani al-Syafi'I, Tabdzib al-Tabdzib, (Beirut: Muassasah, 1996), Juz. III, h. 668. 
bin al-'Abbas dll.

Penilaian para kritikus terhadapnya. Imam Muhammad bin Hanbal mengatakan: imam. Ibn Abi Hatim dari ayahnya berkata: ia imam pada masanya. Ibn al-Syarqi berkata: ia salah seorang dari ulama hadis di Khurasan. ${ }^{21}$

\section{c. Abu Ma'mar}

Nama lengkapnya adalah 'Abd Allah bin 'Amr bin Abi al-Hajjaj, Maysarah, alTamimy al-Minqari, maulahum, Abu Ma'mar al-Muq'ad al-Bashri. Ia wafat tahun $224 \mathrm{H}$.

Diantara guru-gurunya adalah 'Abd al-Warits bin Said, 'Abd al-Wahhab alTsaqafi, Abd al-'Aziz al-Darawardi.

Diantara murid-muridnya adalah 'Abd Allah bin 'Abd al-Rahman, Bukhari, Abu Dawud, Abu al-Ahwash, Abu Hatim, dll.

Penilaian para kritikus terhadapnya. Ibn Ma'in: tsiqah tsabat. Yahya: tsiqah, Ya'qub bin Syaibah: tsiqah tsabat. Al-'Tjli: tsiqah dan menilainya qadariah. Abu Hatim: shaduq mutqin. Ibn Abi Hatim: tsiqah hafid $:^{22}$

\section{d. 'Abd al-Warits}

Nama lengkapnya adalah 'Abd al-Warits bin Sa'id bin Dzakwan al-Tamimi al'Anbari. Ia wafat di Basharah bulan Muharram tahun $180 \mathrm{H}$.

Diantara guru-gurunya adalah Sa'id bin Abi 'Arubah, 'Abd al-Aziz bin Shuhaib, Syu'aib bin al-Habhab, Abi al-Tiyah, Sulaiman al-Taymi, al-Qasim bin Mihran dll.

Diantara murid-muridnya adalah Abu Ma'mar al-Muq'adi, al-Tsauri, 'Abd alShamad (anaknya), Abu Salamah, Musaddad, Abu 'Ashim al-Nabi Saw.l dll.

Penilaian kritikus terhadapnya. Menurut Yahya bin Sa'id: tsabat. Abu Zur'ah: tsiqah. Abu Hatim: shaduq. Al-Nasa'i: tsiqah tsabat. Ibn Sa'ad: tsiqah buijah. Ibn Numair dan al-'Tjli menilainya tsiqah. Al-Saji berkata: ia berpandangan qadariah, shaduq dan mutqin. ${ }^{23}$

\section{e. Sa'id bin Abi 'Arubah}

Nama lengkapnya Sa'id bin Abi 'Arubah. Namanya Mihran, al-'Adawy maula bani 'Ady bin Yasykar, Abu al-Nadhr al-Bashri. Ia wafat tahun $156 \mathrm{H}$.

Diantara guru-gurunya adalah Qatadah, Abi al-Tiyah, Nadhr bin Anas dll.

Diantara murid-muridnya adalah 'Abd al-Warits bin Sa'id, al-A'masy, Syu'bah, Khalid bin al-Harits, Yahya al-Qaththan, Sahal bin Yusuf.

Penilaian para kritikus terhadapnya. Abu Hatim: Sa'id bin Abi 'Arubah tidak memiliki kitab namun ia menghafalnya. Ibn Ma'in dan Nasa'i: tsigah. Abu Zur'ah: tsiqah ma'mun. Ibn Abi Khaitsamah: atsbat al-nas fi Qatadah. Ibn Sa'ad: tsiqah, katsir al-hadis kemudian mencampuradukkan hadis di masa tuanya. ${ }^{24}$

\section{f. Qatadah}

Nama lengkapnya adalah Qatadah bin Di'amah bin Qatadah bin 'Aziz bin 'Amr bin Rabi'ah bin 'Amr bin al-Harits bin Sadus, Abu al-Khaththab al-Sadusi al-Bashri.

\footnotetext{
${ }^{21}$ Ibid, Juz. II, h. 373

${ }^{22}$ Ibid, juz II, h. 392

${ }^{23} \mathrm{Ibid}$, juz.II, h. 635 .

${ }^{24}$ Ibid, juz.II, h. 34
} 
Ia dilahirkan tahun $61 \mathrm{H}$ dan wafat tahun 117.

Diantara guru-gurunya adalah Anas bin Malik, Sa'id bin al-Musayyab, 'Ikrimah, Abi Sa'id al-Khudri, Hafshah binti Sirin, dll.

Diantara murid-muridnya adalah Sa'id bin Abi ‘Arubah, Yunus al-Iskafi, Hisyam al-Dustuwa'I, al-Auza'I, Abu 'Awanah, dll.

Penilaian kritikus terhadapnya. Ibn Sirin: Qatadah orang yang paling hafal. Yahya bin Ma'in: tsiqah. Abu Zur'ah: Qatadah merupakan orang yang paling berilmu diantara murid al-Hasan. Abu Hatim: orang yang paling tsiqah dari murid Anas sesudah alZuhri. ${ }^{25}$

\section{g. Anas}

Nama lengkapnya adalah Anas bin Malik bin al-Nadhr bin Dhamdham bin Zaid bin Haram bin Jundab bin 'Amir bin Ghanm bin 'Adi bin al-Najjar al-Anshari Abu Hamzah al-Madani, pembantu Rasulullah dan tinggal di Bashrah. Hammam berkata, dari Qatadah: ia wafat tahun $91 \mathrm{H}$. Ma' an bin 'Isa berkata: ia wafat tahun $92 \mathrm{H}$. Ibn 'Ulayyah dll berkata: ia wafat tahun $93 \mathrm{H}$.

Diantara guru-gurunya adalah Nabi Saw., Abu Bakar, 'Umar, Utsman, Fathimah dll.

Diantara murid-muridnya adalah Qatadah, al-Hasan, Sulaiman al-Taimiy, Abu Qilabah, Muhammad bin Sirin, al-Zuhri, Sa’id bin Zubair, dll.

Penilaian para kritikus terhadapnya. Abu Hurairah berkata: tidak ada yang shalatnya mirip Rasulullah selain Anas. Dari al-Zuhri dari Anas berkata: ketika Rasulullah datang ke Madinah saya waktu itu berumur 10 tahun. $^{26}$

Berikut ini adalah biodata dan kritik para perawi hadis riwayat al-Tirmizi dalam bentuk tabel yang penulis sarikan dari CD Program Mausu'ah al-Hadis al-Syarif:

${ }^{25} \mathrm{Ibid}$, juz. III, h. 428

${ }^{26} \mathrm{Ibid}$, juz. I, h. 190 


\begin{tabular}{|c|c|c|c|c|c|c|}
\hline و التعديل & تلميذ & شيخ & ترجمة & الحديث رواة & المخرج & نمرة \\
\hline 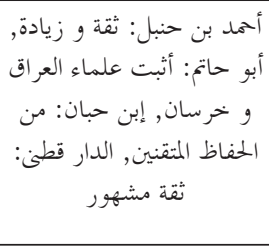 & أحد شيوخ الإمام & 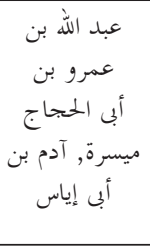 & 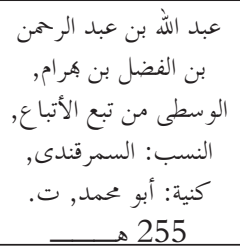 & عبد الرحمن الله بن & \multirow[t]{6}{*}{ الترميذى } & \multirow[t]{6}{*}{1} \\
\hline 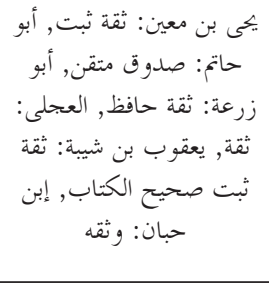 & عبد الرحمن الله بن & بن سعبد الوارث & 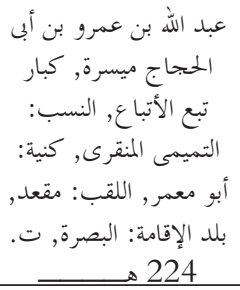 & ألله بن عمر عبد & & \\
\hline 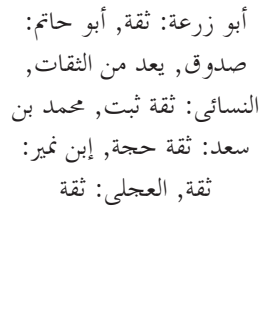 & 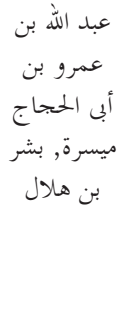 & سعرو الحسد مهر ان, أبى & 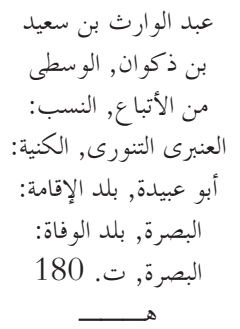 & عبد الوارث & & \\
\hline 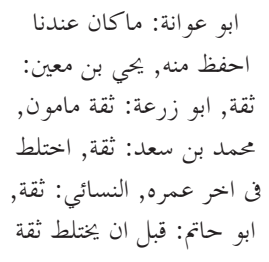 & عبد بن الوارث & قتادة بن دعامة & 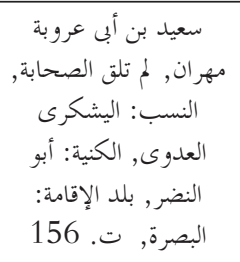 & سعيد بن أبى & & \\
\hline 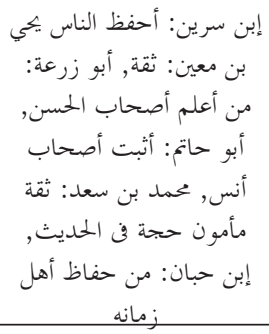 & سعيد سبد بروة بن & بشير بن النضر مالك & 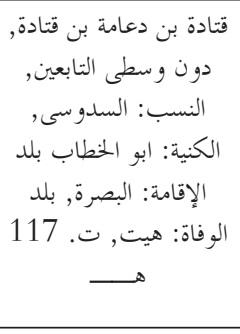 & قتادة & & \\
\hline أعلى مراتب العدالة و & قعادة قعادة بن & عثماب & 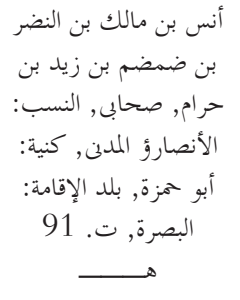 & أنس & & \\
\hline
\end{tabular}


b. Analisa Kualitas Sanad

Berdasarkan data biografi para perawi yang telah dipaparkan pada tabel di atas dapat disimpulkan:

1. Hadis dengan jalur riwayat al-Tirmizi dapat dinilai bersambung dengan beberapa sebab yakni: a. Dari segi umur, antara satu perawi dengan perawi lainnya terdapat jarak usia yang memungkinkan mereka untuk bertemu. Jarak terpanjang adalah antara perawi Abu Ma'mar dengan 'Abd al-Warits yakni 44 tahun sedang perawi lainnya lebih pendek jarak waktunya. b. Dari segi hubungan antara guru dan murid nampak semua perawi adalah guru dan murid bagi perawi lainnya. c. Semua perawi berdomisili di Bashrah yang memungkinkan mereka semua bertemu. Dengan fakta di atas, dapat dinyatakan bahwa jalur hadis tersebut bersambung.

2. Dari segi ke'adalahan dan kedhabitan, dapat dinyatakan bahwa jalur riwayat alTirmizi adalah 'adil dan dhabit. Hal ini didasarkan dari penilaian seluruh kritikus yang menyatakan seluruh perawi dengan pernyataan positif (ta'di) sehingga sanadnya kuat. Meski Sa'id bin Abi 'Arubah dinilai sebagai perawi mukbtalith (mencampuradukkan hadis di masa tuanya) namun, sebagaimana yang dinyatakan oleh Ibn Hibban, ia berstatus tsiqah sebelum masa ikhtilathnya. Para kritikus tidak menilainya mukhtalith ketika meriwayatkan hadis ini. Berdasarkan fakta di atas, dari tiga unsur kaedah kesahehan sanad yakni ketersambungan sanad, ke'adalahan dan kedhabitan maka dapat disimpulkan bahwa sanad hadis jalur al-Tirmizi adalah shahih. Namun demikian, al-Tirmizi menilai hadis tersebut dengan penilaian hasan shabih gharib. Menurut ulama, penggabungan kualitas hasan dengan shahih bisa berarti bahwa hadis tersebut memiliki dua jalur sanad dimana jalur pertama berkualitas hasan sedang jalur lainnya berkualitas shahih. Sedang bila jalur sanad tersebut satu maka ulama memberikan penjelasan dengan mengatakan bahwa dalam menilai jalur tersebut terjadi perbedaan diantara ulama dimana sebagian mengatakan hasan sedang yang lain shahih dan sulit untuk mengkompromikan antara keduanya. Adapun gharib adalah hubungannya dengan jalur sanad tunggal. ${ }^{27}$ Menurut penulis, pernyataan al-Tirmizi yang menilai hasan hadis tersebut karena diantara para perawinya terdapat perawi yang mukhtalith yakni Said bin Abi Arubah. Sedang penilaiannya gharib terhadap hadis tersebut dikarenakan al-Tirmizi hanya menemukan atau meriwayatkan satu jalur periwayatan yakni jalur sanad yang ia kutip dalam kitab hadisnya.

\section{Kritik Matan.}

Sebagaimana dijelaskan terdahulu, kaedah kesahihan matan hadis terdiri dari dua hal yakni terbebas dari syadz dan illah hadis. Syadz menurut pengertian ulama hadis adalah hadis yang diriwayatkan perawi maqbul bertentangan dengan riwayat perawi yang kuat. Sedang 'illah adalah hadis yang lahirnya tampak selamat dari kecacatan namun setelah diteliti akan nampak cacatnya baik karena memaushukan yang mursal, memarfu'kan yang mauquf atau memasukkan hadis pada hadis lainnya dan lainnya. ${ }^{28}$

\footnotetext{
${ }^{27}$ Muhammad Ajaj al-Khatib, Ushul al-Hadis..., h. 335

${ }^{28}$ Muhammad Jamal al-Din al-Qasimi, Qawa'id al-Tahdits min Funun Mushthalab al-Hadis, (Mesir: 'Isa al-Babiy al-Halabiy, 1971), h. 130
} 
Menurut Syuhudi, ada tiga langkah yang harus dilakukan dalam penelitian matan yakni; 1. Meneliti matan dengan melihat kualitas sanadnya, 2. Meneliti susunan lafal berbagai matan yang semakna, 3. Meneliti kandungan matan. ${ }^{29}$ Meneliti susunan lafal berkaitan dengan unsur ke'illaban hadis sedang meneliti kandungan matan berkenaan dengan kesyadzan hadis

Berdasarkan langkah metodologis dalam penelitian matan tersebut, Arifuddin Ahmad kemudian merincinya dengan memasukkan kaedah minor dalam syadz dan illah pada matan hadis. Unsur kaedah minor syad₹, menurutnya, adalah adalah 1. Sanad hadis bersangkutan tidak menyendiri; 2. Matan hadis bersangkutan tidak bertentangan dengan matan hadis yang sanadnya lebih kuat; 3 Matan hadis bersangkutan tidak bertentangan dengan al-Qur'an; dan 4. Matan hadis bersangkutan tidak bertentangan dengan akal dan fakta sejarah. ${ }^{30}$ Di sisi lain, al-Adhlaby menyebutkan bahwa suatu matan hadis dapat diterima kehujjahannya apabila: (1) Tidak bertentangan dengan Alquran; (2) tidak bertentangan dengan hadis lainnya yang lebih kuat; (3) tidak bertentangan dengan indera, akal sehat dan fakta sejarah; dan (4) matan hadis menunjukkan ciri-ciri sabda keNabian. ${ }^{31}$

Sedang kaidah minor matan hadis yang mengandung 'illah adalah 1. Matan hadis bersangkutan tidak mengandung $i d r a j{ }^{32}$ (sisipan); 2. Matan hadis bersangkutan tidak mengandung riyadah ${ }^{33}$ (tambahan); 3. Tidak terjadi maqlub ${ }^{34}$ (pergantian lafal atau kalimat) bagi matan hadis bersangkutan; 4. Tidak terjadi idbthirab (pertentangan yang tidak dapat dikompromikan) bagi matan hadis bersangkutan; dan 5. Tidak terjadi kerancuan lafal dan penyimpangan makna yang jauh dari matan hadis bersangkutan.

${ }^{29}$ M. Syuhudi Ismail, Metodologi Penelitian ..., h. 121

${ }^{30}$ Arifuddin Ahmad, Paradigma Baru Memahami Hadis Nabi Saw.: Refleksi Pemikiran Pembaruan Prof. Dr. Muhammad Syubudi Ismail, (Jakarta: MSCC, 2005), h. 108.

${ }^{31}$ Shalahuddin Ahmad al-Adhlaby, Manhaj Naqd al-Matan 'inda' Ulami al-Hadis al-Nabawiy, (Beirut: Dar al-Afaq al-Jadidah, t.th.), h. 238; Bandingkan dengan pendapat al-Khatib al-Baghdadi, alKifayah fi 'Tlmi al-Riwayah, (Mesir: al-Mathba'ah al-Sa'adah, 1972), h. 206-207.

${ }^{32}$ Idraj adalah tambahan yang diberikan oleh salah seorang rawi baik oleh generasi sahabat maupun sesudahnya, yang tambahan tersebut bersambung dengan matan hadis asli yang berasal dari Rasulullah. Penambahan tersebut dapat terjadi pada permulaan, pertengahan maupun akhir dari suatu matan dan biasanya merupakan penafsiran atau keterangan-keterangan kandungan hukum untuk kata-kata atau pernyataan dari bagian matan tertentu yang dikemukakan oleh rawi tertentu. Lihat, Nuruddin 'Itr, Manhaj al-Naqd fi 'Ulum al-Hadis, (Beirut: Dar al-Fikr, 1988), h. 440 .

${ }^{33}$ Secara bahasa, kata ziyadah berarti tambahan. Menurut istilah ilmu hadis, ziyadah pada matan adalah tambahan lafazh atau kalimat yang terdapat pada matan yang ditambahkan oleh rawi tertentu, sementara rawi lain tidak mengemukakannya. Nuruddin 'Itr, Manhaj al-Naqd fi $\mathrm{Ulm}$ al-Hadis, diterjemahkan oleh Mujiyo dengan judul 'Ulum al-Hadis 2, (Cet. II; Bandung: Rosda Karya, 1997), h. 230.

${ }^{34}$ Hadis disebut maqlub maksudnya hadis yang terjadi pemutarbalikan pada redaksi hadis, yang dilakukan oleh seorang rawi baik disengaja maupun tidak. Indikasi adanya pemutarbalikan itu terlihat pada: 1) seorang rawi mendahulukan suatu matan hadis yang seharusnya diletakkan pada akhir matan atau sebaliknya; 2) seorang rawi menjadikan suatu matan hadis (yang sudah jelas sanadnya) ditempatkan pada sanad yang lain. Mahmud Thahan, Taysir Mushthalah al-Hadis, (Beirut: Dar al-Fikr, 1985), h. 108. 
Jika 'illah hadis itu mengandung pertentangan dengan hadis lain yang lebih kuat, maka matan hadis tersebut sekaligus mengandung syudzud ${ }^{35}$

Untuk meneliti kesahehan matan, penulis menggunakan kaedah metodologis yang dikemukakan Syuhudi Ismail di atas.

1. Meneliti kualitas sanad

Sebagaimana dijelaskan di atas, jalur sanad hadis yang diteliti yakni riwayat alTirmizi berkualitas shahih.

2. Meneliti susunan lafal berbagai matan yang semakna

Berdasarkan hadis yang disebutkan di atas, terdapat 13 hadis dari 7 kitab hadis dengan berbagai variannya. Pada riwayat al-Bukhari terdapat 3 hadis, al-Tirmizi 2 hadis, Ibn Majah 2 hadis, al-Nasa'i 1 hadis, Abu Ya'la 1 hadis dan al-Bazzar 2 hadis. Di sini penulis berusaha membandingkan matan hadis yang diriwayatkan al-Tirmizi dari Abd Allah bin 'Abd al-Rahman dengan berbagai matan hadis dari jalur sanad lainnya. Untuk mendapat gambaran lebih jelas mengenai varian hadis tersebut berikut adalah tabel matan hadis:

\begin{tabular}{|c|c|c|c|c|}
\hline $\begin{array}{l}\text { Varian } \\
\text { IV }\end{array}$ & $\begin{array}{c}\text { Varian } \\
\text { III }\end{array}$ & $\begin{array}{l}\text { Varian } \\
\text { II }\end{array}$ & $\begin{array}{c}\text { Varian } \\
\text { I }\end{array}$ & المخرج \\
\hline فعلام كانوا يأكلون قال على & ولا فل أكل خبزا مرققا حتى مات & على خوان & ما ما أكل رسول الله & 2. 1 إبن ماجة الترميذى \\
\hline لقتادة, فبزلام كرقانو, قالك: فقلت & ولا فن سكرجة & فن خوان & ما أكل رسول اللة & 3. الترميذى \\
\hline قال على هذه السفر & حتى مات & على خوان & ما رأيت رسول الله & 4. إبن ماجة \\
\hline ولا أكل على خوان قط | & ولا خبز له مرقق قط & على سكرجة قط & ما علمت البى أكل & 5. 5 البخارى \\
\hline فعلام كانوا يأكلون قال على & ولا ف سكرجة & على خوان & مـا أكل البى & 6. 6 البخارى \\
\hline قال على السفر مرقق | علام يأكلون & ولا في سكر خبزا مرققا حتى مات & على خوان & ما لم يأكل البنى & 8. \\
\hline فعلام كانوا يأكلون قال علداد & ولا سكرجة & في خوان & ما أكل رسول الله & 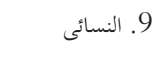 \\
\hline 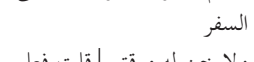 & ولا فن سكرجة & على خوان وقال مرة أخرى & ما أكل رسول الله & 01. النسائى \\
\hline هذا كانوا يأكلون قال على ملى فعلى & ولا في سكرجة قط & على خوان مائده & ما أكل البى & 11. أبو يعلى \\
\hline ولا خبز له مرقق الحبز & لحق به اللة فل سكرجة حتى & على خوان & ما أكل رسول اللة & 21. البزار \\
\hline علأنس علام كانو السف أ يأكلون نقال & ولا أكل فن سكرحة & على خوان & ما أكل رسول الله & 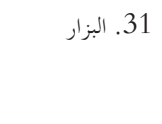 \\
\hline 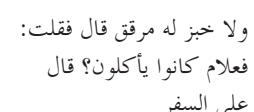 & & & & \\
\hline
\end{tabular}

${ }^{35}$ Arifuddin Ahmad, Paradigma Baru ..., h. 109 
Perlu dijelaskan bahwa varian I sampai IV merupakan kutipan matan hadis secara lengkap berdasarkan jalur perawinya. Sedang dua perawi pertama yakni al-Tirmizi merupakan periwayat yang hadisnya menjadi fokus kajian.

Ada beberapa hal yang perlu ditegaskan:

a. Seluruh hadis tersebut adalah hadis filiyah yakni perbuatan Nabi Saw. yang direkam oleh sahabat Anas bin Malik terkait dengan kebiasaan dan tata cara makan Nabi Saw. Ketersendirian Anas bin Malik dalam periwayatan hadis di atas adalah wajar mengingat ia telah menjadi pembantu Nabi Saw. sejak masa kecil yakni ketika berusia 10 tahun saat kedatangan Nabi Saw. ke Madinah.

b. Hadis tersebut diceritakan Anas kepada muridnya dalam satu versi yang sama namun kemudian diriwayatkan oleh dua muridnya yakni Yunus dan Said bin Abi Arubah atau perawi yang berada di bawahnya dengan berbagai versi. Berdasarkan kajian terhadap matan hadis, ada tiga versi hadis yang berbeda dimana masing-masing memiliki ciri tertentu. Hadis dari perawi Mu'adz bin Hisyam memiliki empat komponen utama yang disandarkan padanya yakni kata 'khiwan', 'sukkarajah', 'kbubz. muraqqaq' dan 'fa'ala ma kanu ya'kulun'. Dengan ciri khas ini menunjukkan bahwa riwayat Ibn Majah dari Muhammad al-Mutsanna terdapat teks yang hilang yakni kata 'kbubz al-muraqqaq'. Sedang versi kedua adalah yang disandarkan pada Abu Ma'mar dengan ciri utama yakni kata 'khiwan' dan 'khubz al-muraqqaq hatta mata'. Dibanding versi pertama, versi kedua ini tidak memuat kata 'sukearajab' dan 'fa'ala ma kanu ya'kulun' yang merupakan ciri khas versi pertama. Namun versi kedua ini terdapat tambahan kata ' 'batta mata' yang menjadi ciri jalur periwayatannya. Sedang versi ketiga dari riwayat Muhammad bin Hasyim dengan dua komponen kata yakni 'kbiwan' dan 'sukkarajah hatta labiqa Allab'. Karena tidak terdapat jalur lain dari murid Anas bin Malik maka ada beberapa kemungkinan yang dapat ditarik yakni 1. Versi lengkap hadis tersebut adalah yang sandarkan pada Mu'adz bin Hisyam sedang dua versi lainnya merupakan versi pendek dari hadis tersebut. 2. Versi Muadz bin Hisyam sesungguhnya merupakan gabungan dari dua versi lainnya. 3. Hadis tersebut memang diriwayatkan secara berbeda oleh perawi Qatadah kepada muridnya.

Dalam hal ini penulis berpandangan pada asumsi pertama di atas yakni bahwa hadis tersebut sesungguhnya bukanlah tana' $m u^{36}$ namun lebih pada satu peristiwa. Adapun perbedaan yang terjadi karena dua versi lainnya diriwayatkan dalam bentuk versi pendek. Sehingga dengan ini hadis riwayat al-Tirmizi dari jalur Abu Ma'mar adalah versi pendek periwayatan panjang dari Muadz bin Hisyam.

c. Tidak ada pertentangan antara satu hadis dengan hadis lainnya.

Berdasarkan matan di atas, tiga versi periwayatan hadis di atas tidak terdapat pertentangan antara satu dengan lainnya. Satu versi merupakan periwayatan yang

\footnotetext{
${ }^{36}$ 'Tanawwu' secara dalam bahasa Arab berarti beragam. Dalam ilmu hadis, istilah ini digunakan untuk menunjukkan adanya kesamaan/kemiripan satu redaksi hadis dengan redaksi hadis lainnya dari jalur sanad yang berbeda namun sesungguhnya tidak diucapkan Nabi Saw. dalam satu peristiwa yang sama. Kemiripan tersebut barangkali terjadi karena adanya suatu kondisi yang serupa sehingga Nabi Saw. mengungkapkan dengan sabda yang hampir serupa namun berbeda rentang waktu dan masanya. Karenanya, antara kedua redaksi hadis tetap memiliki perbedaan.
} 
lengkap sedang dua versi lainnya merupakan versi matan yang pendek. Adapun unsur 'illah dalam hadis tersebut seperti ziyadah, idraj, maqlub dan idhthirab tidak ditemukan pada dua jalur periwayatan yang tengah diteliti yakni jalur al-Tirmizi dari Abd Allah bin Abd al-Rahman. Namun demikian, kedua jalur tersebut bukan jalur sempurna karena terdapat beberapa kata yang hilang dari versi lengkapnya. 3. Meneliti kandungan matan

Sebagaimana dijelaskan Arifuddin Ahmad, meneliti kandungan matan berarti meneliti kemungkinan ada atau tidaknya syadz dalam hadis tersebut. Adapun unsurunsur kaedah minor syadz adalah pertentangan muatannya dengan kandungan hadis yang lebih kuat, pertentangannya dengan al-Quran atau akal dan fakta sejarah. Hadis di atas berbicara tentang kesederhanaan Nabi Saw. dalam makan dan apa yang menjadi makanan beliau sehari-hari. Nabi Saw. tidak makan di atas piring maupun meja makan namun hanya makan di atas daun kurma. Adapun makanan yang dimakan beliau adalah roti yang keras.

Menurut Ibn Baththal, sebagaimana dikutip Ibn Hajar dalam kitab Syarahnya, mengatakan bahwa perbuatan Nabi Saw. yang tidak makan di atas piring dan juga tidak memakan roti yang lembut bertujuan untuk menghindari kelezatan dunia demi mencapai kelezatan akhirat yang kekal. Sedang harta dicari untuk menggapai kehidupan akhirat. Dengan ini, tindakan Nabi Saw. tersebut tidak berarti menunjukkan bahwa kemiskinan lebih mulia dibandingkan menjadi kaya. Namun untuk menunjukkan kemuliaan sikap qana'ah, menahan diri dari kenikmatan dunia, dan tidak berlebihlebihan dalam menikmati kelezatannya. Perilaku Nabi Saw. tersebut diperkuat dengan hadis dari Ibn Umar yang berbunyi:

$$
\text { أبى الدنيا قال المنذرى وسنده جيد عبد من الدنيا شيثا إلا نقص من درجاته , وإن كان عند الله كريما،، أخرجه ابن }
$$

Artinya: Tidak ada seorang hamba yang diberi sedikit pun kenikmatan dunia

kecuali akan berkurang derajatnya meskipun di sisi Allah ia mulia ${ }^{37}$

Dengan demikian, hadis yang berbicara tentang tata cara dan kebiasaan makan Nabi Saw. tidak bertentangan dengan hadis lainnya sebagaimana dijelaskan di atas.

Al-Qur'an banyak berbicara tentang kemuliaan hidup akhirat dibanding kesenangan dunia sehingga menganjurkan orang mukmin untuk lebih mendapatkan akhirat meski pada kesempatan lain tidak juga melupakan kehidupan dunia keseluruhan. Bagaimana pun kehidupan dunia berpengaruh dalam mencapai kenikmatan akhirat bila disikapi secara benar. Apa yang diperoleh dari harta dunia dimanfaatkan untuk mendapatkan kehidupan akhirat. Sikap inilah yang dimaksud dengan kehidupan akhirat lebih mulia dibandingkan dunia. Hal ini menunjukkan bahwa sesungguhnya kenikmatan dunia tidaklah tercela bila digunakan untuk mendapatkan kemuliaan yang lebih besar di akhirat. Pada dasarnya, sifat manusia adalah senang hal-hal pragmatis dan realistis. Kehidupan dunia adalah real sedang akhirat ada dibelakang realitas (beyond the real) yang mudah bagi manusia untuk melupakannya. Surah al-An'am/6: 32

${ }^{37}$ Ibn Hajar al-Asqalani, Fath al-Bary bi Syarh Shabih al-Bukhari, CD Program Musu'ah al-Hadis al-Syarif. 
mengingatkan akan nilai akhirat yang lebih baik di banding dunia. Allah berfirman:

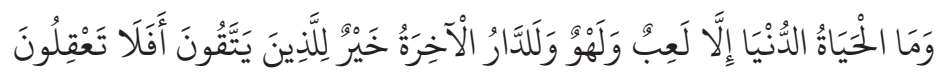

Artinya: Dan tiadalab kebidupan dunia ini, selain dari main-main dan senda gurau belaka. Dan sungguh kampung akbirat itu lebih baik bagi orang-orang yang bertakwa. Maka tidakekah kamu memahaminya?

Dalam surah al-Ra'd/13: 26, al-Qur'an menegaskan bahwa kehidupan dunia adalah kenikmatan sesaat. Allah berfirman:

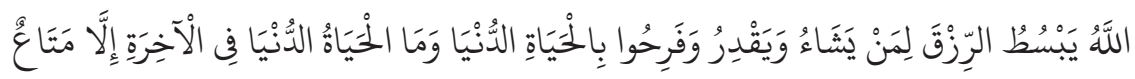

Artinya: Allah meluaskan ręki dan menyempitkannya bagi siapa yang Dia

kehendaki. Mereka bergembira dengan kehidupan di dunia, padahal kehidupan dunia itu (dibanding dengan) kebidupan akbirat, hanyalah kesenangan (yang sedikit).

Dengan demikian, antara kandungan matan hadis berkenaan dengan tidak makannya Nabi Saw. di atas piring dan meja serta kesederhanaannya dalam menikmati makanan dengan tidak memakan roti yang lembut merupakan sikap zuhud akan kehidupan dunia. Sikap ini tentunya tidak bertentangan dengan ayat-ayat al-Qur'an sebagaimana dijelaskan di atas.

Makan di piring atau dalam hadis di atas disebut dengan 'uskurrajab' merupakan tradisi makan orang Persia. 'Uskurrajab' adalah bahasa Persi yang di Arab kan. Ibn Makki mengatakan bahwa 'uskurrajab' bermakna ceper besar dan adapula yang kecil digunakan untuk makan. Menurutnya, orang-orang non Arab menggunakannya sebagai tempat makan untuk menunjukkan kesombongan dan membangkitkan selera. Adapun makanan yang dihidangkan untuk dimakan berupa makanan-makanan yang mudah dicerna. Penulis Syarh Tirmizi berpendapat bahwa Nabi Saw. dan sahabat tidak makan di atas 'sukkarajab' boleh jadi karena alat tersebut belum dibuat di Arab pada masa itu. Atau sebagai bentuk memandang rendah alat tersebut karena kebiasaan mereka berkumpul untuk makan dengan menggunakannya dan makanan yang disajikan adalah yang mudah dicerna dimana pada umumnya tidak mengenyangkan. ${ }^{38}$

Bila makan di atas sukkarajah' merupakan tradisi orang-orang Persia untuk maksud menyombongkan diri dan bermewah-mewahan maka secara akal wajar saja Nabi Saw. dan para sahabatnya tidak menyukai makan di atas alat tersebut. Dalam segala sisi kehidupan, Nabi Saw. selalu mencontohkan kesederhanaan dan menghindari kemewahan dunia termasuk dalam urusan makan. Sehingga sangat dapat dipahami apabila beliau dan para sahabat tidak makan di atas 'khiwan' atau 'sukkarajah' karena dua hal tersebut mencerminkan kemewahan hidup.

Dengan makna hadis ini maka penulis berkesimpulan bahwa hadis tersebut tidak bertentangan dengan al-Qur'an, hadis yang lebih kuat maupun akal sehat yang ditinjau dari segi sejarah penggunaan alat tersebut. Dengan demikian hadis tersebut berkualitas shahih baik sanad maupun matannya. 


\section{Simpulan}

Dalam kutub al-tis'ah, terdapat delapan hadis yang berbicara tentang tata cara dan kebiasaan makan Nabi Saw. di atas daun kurma dan tidak di atas piring atau meja makan. Hadis tersebut tersebar dalam empat kitab hadis yakni al-Bukhari ada tiga hadis, al-Tirmizi memuat dua hadis, Ibn Majah terdapat dua hadis dan Ahmad bin Hanbal memuat satu hadis. Di luar kitab tersebut, ada beberapa kitab yang memuat hadis serupa yakni Sunnan Kubra li an-Nasa'i sebanyak dua hadis, Musnad Abu Ya'la memuat satu hadis dan Musnad al-Bazzar memuat dua hadis.

Berdasarkan hasil penelitian mengenai kualitas sanad dan matannya, penulis berkesimpulan bahwa hadis yang diteliti yakni hadis riwayat al-Tirmizi dari Abdullah bin Abdurrahman adalah shahih. Dalam penelitian sanad ditemukan bahwa jalur periwayatan hadis tersebut seluruh rangkaiannya bersambung, perawinya adalah perawi yang tsiqah ('adil dan dhabit). Sementara dalam penelitian matan ditemukan argumen bahwa matan hadis tersebut adalah hadis filiyah yang diriwayatkan secara beragam oleh murid Qatadah meskipun, menurut penulis, semula diriwayatkan dalam satu versi oleh Anas bin Malik. Selain itu, jalur riwayat yang diteliti, yakni riwayat al-Tirmizi, tidak ditemukan unsur 'illah berupa ziyadah, idraj, taqlib maupun idhthirab namun sebaliknya, redaksi matan hadisnya merupakan periwayatan yang tidak lengkap. Sedang pada unsur syadz, tidak ditemukan pertentangan dengan redaksi hadis yang serupa dari jalur sanad lain. Dari aspek kritik matan, dapat disimpulkan bahwa muatan hadis tersebut tidak bertentangan dengan al-Qur'an, hadis yang lebih shahih, akal dan fakta sejarah. Bahkan, al-quran dan hadis-hadis lainnya turut mendukung muatan hadis yang diteliti. Sehingga, berdasarkan hal tersebut dapat dinyatakan bahwa hadis di atas adalah shahih baik sanad maupun matannya.

\section{Daftar Pustaka}

A.J. Wensinck, al-Mu'jam al-Mufahras li Alfadz al-Hadis al-Nabawi, Leiden E.J. Bril, 1943, juz. III

Abu 'Abd Allah Muhammad bin Isma'il bin Ibrahim bin al-Mughirah bin Bardazabah, Shahih al-Bukhari, Beirut, Dar al-Kutub al-'Ilmiah, 1992, juz. V

Abu Abd Allah Ahmad bin Hanbal, Musnad Abmad bin Hanbal, Riyadh, Bait al-Fakr, 1998

Abu 'Isa Muhammad bin 'Isa bin Saurah al-Tirmidzi, al-Jami' al-Shahih wa huwa Sunan al-Tirmidzi, Beirut, Dar al-Kutub al-'Tlmiyyah, 2000, Juz. III

Abu Muhammad Abd al-Hadi, Thuruq Takbrij Hadis Rasul Allab Shalla Allab 'Alaibi wa Sallam, ttp, Dar al-'Itisham, tth

Abu Muhammad Abd al-Rahman bin Abi Hatim Muhammad bin Idris bin al-Mundzir al-Tamimi al-Handzali al-Razi, Kitab al-Jarh wa al-Ta'dil, Hindi, Dairat al-Ma'arif al-'Utsmaniah, 1953, Juz. IX

Ahmad bin 'Ali bin Hajar Syihab al-Din al-'Asqalani al-Syafi'I, Tahdæib al-Tabdqib, Beirut, Muassasah, 1996, Juz. II 
al-Hadis al-Syarif

Arief Halim, Metodologi Tahqiq Hadis Secara Mudah dan Munasabah, Malaysia, Univ. Sains Malaysia, 2007

Arifuddin Ahmad, Paradigma Baru Memahami Hadis Nabi Saw.: Refleksi Pemikiran Pembaruan Prof. Dr. Muhammad Syubudi Ismail, Jakarta, MSCC, 2005

CD Program Mausu'ah Hadis Syarif Kutub Tis'ah

Jamal al-Din Abi al-Hajjaj Yusuf al-Mizzi, Tahæhib al-Kamal fi Asma al-Rijal, Beirut, Muassasah al-Risalah, 1992, Juz. 32

al-Khatib al-Baghdadi, al-Kifayah fi 'Imi al-Riwayah, Mesir, al-Mathba'ah al-Sa'adah, 1972

Mahmud Thahan, Taysir Mushthalah al-Hadis, Beirut, Dar al-Fikr, 1985

M. Syuhudi Ismail, Metodologi Penelitian Hadis Nabi Saw., Jakarta, Bulan Bintang, 1992, Cet. I

Muhammad 'Ajaj al-Khatib, Ushul al-Hadis: Ulumubu wa Mushthalabubu, Beirut, Dar al-Fikr, 1989

Nuruddin 'Itr, Manhaj al-Naqd fi 'Ulum al-Hadis, Beirut, Dar al-Fikr, 1988

Shalahuddin Ahmad al-Adhibiy, Manhaj Naqd al-Matan 'inda' Ulami al-Hadis al-Nabawiy, Beirut, Dar al-Afaq al-Jadidah, t.th

Shubhi Shalih, 'Ulum al-Hadis wa Mushthalahuh, Beirut, Dar al-'Ulum li al-Malayin, 1988 